\title{
Social neuroscience: Pendekatan multi-level integratif dalam penelitian psikologi sosial
}

\author{
Galang Lufityanto* \\ Fakultas Psikologi, Universitas Gadjah Mada, Daerah Istimewa Yogyakarta
}

\begin{abstract}
Abstrak
Manusia sebagai makhluk biologis yang hidup dalam lingkungan sosial menciptakan kompleksitas dalam kehidupannya. Pendekatan biologis atau sosial yang berdiri sendiri-sendiri sering menyisakan pertanyaan yang belum terjawab. Social Neuroscience merupakan pendekatan mutakhir yang meneliti aspek biologis dalam konteks perilaku sosial manusia, namun demikian pendekatan ini belum terlalu populer di Indonesia. Dengan menggabungkan antara kelebihan pendekatan biologis dan pendekatan sosial, Social Neuroscience berpotensi menjadi suatu metode multi-level integratif yang mampu memahami kompleksitas perilaku manusia secara lebih komprehensif. Artikel ini bertujuan untuk memberikan gambaran umum terkait ruang lingkup, desain penelitian, teknik pengukuran, validasi, serta aplikasi pendekatan Social Neuroscience di Indonesia. Harapannya, berbekal penguasaan metode Social Neuroscience dalam memahami isu psikologisyang majemuk, Indonesia ke depannya akan bisa menjadi salah satu pemain utama dalam perkembangan ilmu Psikologi global.
\end{abstract}

Kata kunci: social neuroscience, metodologi, multi-level, biologis

\begin{abstract}
As biological creatures, humans live in a social environment and creates complexity in their lives. Biological and social perspectives are often being seen as independent to each other, but there is a potential that these two perspectives can be integrated. Social Neuroscience is a cutting-edge approach that examines biological aspects in the context of human social behavior. However, this approach is not yet quite popular in Indonesia. By combining the advantages of biological approaches and social approaches, Social Neuroscience has the potential to become an integrated multi-level method that is able to understand the complexity of human behavior in a more comprehensive manner. This article aims to provide an overview of the scope, research design, measurement techniques, validation, and application of the Social Neuroscience approach in Indonesia. Hopefully, armed with the mastery of the Social Neuroscience method in understanding multiple psychological issues, Indonesia in the future will be able to become one of the main players in the development of global Psychology.
\end{abstract}

Keywords: social neuroscience, methodology, multi-level, biological

\section{Pendahuluan}

$\mathrm{B}=\mathrm{f}(\mathrm{P}, \mathrm{E})$

"Perilaku merupakan fungsi dariindividu (genetik)

dan lingkungannya" - Kurt Lewin

Persamaan yang ditulis oleh Kurt Lewin (1936) dalam bukunya yang berjudul "Principles of Topological Psychology" di atas menunjukkan bahwa perilaku manusia merupakan hasil dari sinergi antara elemen genetik/biologis danlingkungan fisik/sosialnya. Selama lebih dari satu abad, studi tentang perilaku manusia telah banyak diwarnai oleh pendekatan biologis (misal: kedokteran, biologi, fisika, dan lain-lain) dan pendekatan sosial (misal: psikologi, antropologi, sosiologi, sejarah, dan lain-lain). Pendekatan biologis menekankan pada aspek fisiologisyang mem engaruhi perilaku manusia, seperti misal nya pengaruh hormon dopamin terhadap motivasi (Schultz, 2007) atau mekanisme neural yang mendasari perilaku sadar manusia (Edelman, Gally, \& Baars, 2011). Sementara itu, pendekatan sosial lebih menekankan pada konstelasi lingkungan sosial yang mempengaruhi perilaku manusia. Seperti misalnya, pengaruh lingkungan pergaulan sosial terhadap kepercayaan diri (Valkenburg, Peter, \& Schouten, 2006) atau pengaruh budaya terhadap perilaku pembelian (Kacen \& Lee, 2002).

Secara umum, keberadaan dua pendekatan tersebut memiliki arti positif karena menandakan kekayaan paradigma dalam mengkaji fenomena perilaku manusia. Namun di sisi lain, hal itu juga akan semakin memperjelas pendekatan biologis versus sosial sebagai dua entitas paradigma yang berbeda, 
dan bahkan bertolak belakang (Rozin, 2001). Dikatakan bertolak belakang, karena keunggulan satu pendekatan justru menjadi kelemahan bagi pendekatan lainnya. Seperti misalnya pendekatan psikologi sosial sering dikritik memiliki kelemahan dalam hal metodologis, misalnya kompleksitas variabel yang ditelitinya menyulitkan peneliti dalam mengidentifikasi dan mengontrol variabel-variabel pencemar (Forthmann, Holling, Çelik, Storme, \& Lubart, 2017; Moorman \& Podsakoff, 1992). Selain itu, pendekatan sosial juga lebih menitikberatkan pada persepsi subjektifpartisipan (Smedslund, 2016). Kelemahan metodologis ini diduga menjadi salah satu penyebab mengapa penelitian psikologi cenderung sulit direplikasi (Maxwell, Lau, \& Howard, 2015; Shrout \& Rodgers, 2018). Sebaliknya, pendekatan biologi dikritik karena karakteristik penelitiannya yang terlalu reduksionis, tidak kontekstual, dan kurang bisa menjawab isu permasalahan yang kompleks (Greenberg, 2005).

Tidak bisadipungkiri, bahwaperilakumanusia adalah suatu fenomena yang kompleks. Konteks memang tidak bisa dilepaskan dalam memahami perilaku manusia. Namun demikian disiplin ilmu yang mempelajari perilaku manusia, seperti misalnya Psikologi, dihadapkan pada tantangan untuk selalu bisa memprediksi perilaku secara konsisten dan reliabel dalam segala situasi yang ada (contohnya: Alloway \& Alloway, 2010; Newsome, Day, \& Catano, 2000). Hal ini sulit dilakukan tanpa menemukan generator utama dalam perilaku manusia-suatu komponen yang sifatnya bawaan atau hereditas. Di sinilah persamaan yang dikemukan Lewin (1936) di atas menjadi relevan. Formulasi semacam ini sebenarnya cukup lazim ditemukan dalam kajian Psikologi, seperti misalnya dualisme entitas kecerdasan atau intelegensi, yaitu: fluid intelligence dan crystalized intelligence (Horn \& Cattell, 1966). Fluid intelligence dianggap sebagai elemen kecerdasan yang sifatnya bawaan dan sedikit dipengaruhi oleh pengalaman belajar di masa lalu, sedangkan crystalized intelligence banyak diperoleh dari pengalaman belajar. Kedua elemen intelegensi itu bersinergi dalam pembentukan arsitektur kecerdasan manusia umum, yang bukti neurologisnya bisa dilacak dalam penelitian Hampshire, Highfield, Parkin, dan Owen (2012).

Sebagai dua pandangan yang berbeda, pendekatan biologis dan sosial sebenarnya memiliki beberapa titik persinggungan. Titik persinggungan pertama adalah bukti bahwa pengaruh perbedaan budaya ternyata mempengaruhi proses biologisyang sebelumnya dianggap sebagai sesuatu yang universal danbebas budaya. Melaluiteknik pemindaian otak (brain imaging) menggunakan mesin functional magnetic resonance imaging (fMRI), ditemukan bahwa mekanisme neural yang mendasari proses kognitif dasar manusia sangat bervariasi tergantung dari latar belakang budayanya (Lebih lanjut, baca Han \& Northoff, 2008). Ketika diberikan tugas behavioral (respon perilaku) yang sama dalam setting laboratorium, terjadi variasi aktivitas otak; dan variasi tersebut bisa diprediksi dari latar belakang budaya- nya. Selain itu, penelitian yang lain menemukan bahwa partisipan penelitian yang berlatar belakang budaya Barat lebih mampu untuk mengontol perhatian/atensi pada tugas visual di mana objek gambar terpisah dari konteksnya (Hedden, Ketay, Aron, Markus, \& Gabrieli, 2008). Hal ini yang kemudian diistilahkan sebagai "independensi” dalam konteks persepsi visual. Sebaliknya, partisipan berlatar belakang Asia lebih baik dalam mengontrol atensi ketika objek visual yang dilihatnya relevan dengan konteks di sekitarnya, atau diistilahkan sebagai "interdependensi". Fenomena ini memiliki prinsip kerja yang mirip dengan apa yang sering disebut dalam literatur Psikologi Sosial sebagai "individualitas" (analogi dari "dependensi") dan "kolektivitas" (analogi dari "interdependensi") (Hofstede, Hofstede, \& Minkov, 2005; Triandis, 2001). Yang menarik dari temuan ini adalah aspek psikologis yang semula diduga sangat mendasar dan universal, seperti misalnya persepsi visual, ternyata sangat kontekstual dan tergantung dari pengaruh budaya.

Lingkungan fisik-sosial juga ditemukan berpengaruh pada proses kognitif manusia. Penelitian yang dilakukan di Laboratorium Mind, Brain, dan Behaviour Fakultas Psikologi Universitas Gadjah Mada baru-baru ini menemukan bahwa karakteristik pekerjaan mempengaruhi strategi kognitif individu. Lebih lanjut lagi, Lufityanto, dkk (2019) menemukan bahwa pengendara ojek online lebih memanfaatkan kemampuan visual-spasial daripada mengandalkan ingatan verbal mereka dalam menemukan lokasi yang dituju. Sebaliknya, pengendara ojek konvensional justru lebih mempercayai ingatan verbal tentang lokasi tempat yang dituju. Penelitian ini dilakukan menggunakan permainan labirin di komputer dengan memperhitungkan durasi waktu dalam menyelesaikan permainan itu dan berapa kali pemain mengakses bantuan peta visual maupun petunjuk arah yang sifatnya verbal.

Titik persinggungan kedua adalah bukti bahwa adanya variasi dalam data fisiologis terkait dengan perilaku manusia ditentukan dari pengalaman yang telah terjadi (Lebih lanjut, baca Kosslyn, dkk, 2002). Seperti misalnya, literatur terdahulu menunjukkan bahwa data fisiologis di sistem limbik manusia yang terkait dengan pemrosesan emosi sangat bervariasi terkait dengan bagaimana subjek mengalami peristiwa emosional di masa lalunya (Ekman \& Davidson, 1994). Dengan demikian, pengalaman di masa lalu turut berkontribusi dalam mendesain ulang respon biologis terhadap kejadian yang akan terjadi. Penelitian Lufityanto dan Pearson (2019) juga menunjukkan bahwa data fisiologis, yaitu galvanic skin responses, dalam pengambilan keputusan berdasarkan emosi sangat tergantung pada tipe pemrosesan informasi mereka. Subjek yang mengkategorisasikan dirinya sebagai intuitive thinker cenderunglebih mudah memanfaatkan emosi sebagai alat bantu pengambilan keputusan mereka, dibandingkan dengan subjek yang masuk dalam kategori rational thinker. Subjek mengategorisasikan dirinya sebagai intuitive atau rational thinker berdasarkan 
kuesioner yang menanyakan bagaimana keputusan di masa lalu umumnya dibuat; apakah berdasarkan emosi atau murni logika.

Adanya titik persilangan antara pendekatan biologis dan sosial menumbuhkan harapan munculnya suatu paradigma baru yang mengawinkan kedua kelebihan pendekatan ini. Pada awal tahun 1990-an, peneliti di bidang Cognitive Neuroscience mulai tertarik untuk meneliti seputar topik Social Cognition, terutama mekanisme neural yang mendasari perilaku sosial dan hubungan interpersonal (Cacioppo, dkk., 2002; Kosslyn dkk., 2002). Social Cognition merupakan kajian kognitif terkait persepsi individu terhadap lingkungan sosialnya (Higgins, 2000). Dikategorikan sebagai "sosial" karena kajian ini membahas hubungan antar individu. Sementara itu, dikategorikan sebagai "kognitif" karena kajian ini melakukan analisis pada elemen kognitif dari perilaku sosial tersebut. Sebagai contohnya, penelitian Fiske, Cuddy, dan Glick (2007) yang mengkaji bias persepsi pada perilaku menghargai kompetensi orang lain. Lebih lanjut lagi penelitian ini menemukan bahwa bentuk penghargaan (yaitu, warmth versus competence) terhadap orang lain sangat ditentukan oleh persepsi ada/tidaknya kompetisi dalam hubungan interpersonal ini.

Lantas bagaimanakah posisi pendekatan Social Neuroscience ketika dihadapkan dengan Social Cognition? Pendekatan Social Neuroscience mengkaji lebih dalam lagi terkait mekanisme intrinsik yang mendasari proses kognitif dalam perilaku sosial (Adolphs, 2001). Mekanisme intrinsikyang dimaksud di sini adalah proses biologis yang mendasari suatu perilaku. Artikel ini akan secara lebih lanjut membahas ruang lingkup, desain penelitian, instrumen pengukuran, dan validasi pengukuran dengan konteks kajian Social Neuroscience.

\section{Ruang Lingkup Social Neuroscience}

Social Neuroscience merupakan titik pertemuan atau hubungan antara pendekatan biologis dan sosial. Pendekatan ini mengombinasikan kelebihankelebihan dari dua pendekatan tersebut untuk menjawab kebutuhan riil di lapangan, namun tetap berdasarkan pada pendekatan yang lebih objektif. Kajian Social Neuroscience berfokus pada fenomenafenomena Social Cognition yang dikaji melalui pendekatan biologis, seperti misalnya struktur neural, genetik, dan sistem neurotransmiter (Adolphs, 2001). Terkait dengan struktur neural pada manusia, penelitian Saxe (2006) telah menunjukkan bagianbagian otak yang mengontrol perilaku sosial yang spesifik, misalnya: bagian ventral medial prefrontal cortex yang terlibat pada pemrosesan emosi simpatik dan dorsal medial prefrontal cortex yang terlibat dalam perilaku kolaboratif. Dalam level selular dan molekular, Iacoboni (2009) juga telah berhasil menemukan mirror neuron yang diduga memiliki kontribusi terhadap perasaan empati terhadap orang lain.

Lampiran 1 menunjukkan beberapa contoh penelitian Social Neuroscience yang telah dilakukan dan masih dikembangkan hingga detik ini. Terlihat bahwa beberapa elemen biologis seperti misalnya sistem syaraf, gen, neuroendokrin, dan bahkan sistem imunitas manusia menjadi elemen yang telah lama dikaji dalam studi Social Neuroscience. Sistem syaraf menjadi objek yang sering diteliti, dan lazimnya menjadikan otak sebagai kajian utama. Sistem neuroendokrin yang memproduksi bermacam-macam hormon dan neurotransmiter juga ditemukan terlibat dalam proses sosial. Selanjutnya, sistem kekebalan tubuh yang baik dapat menyebabkan individu relatif kuat dalam menghadapi stres, termasuk di antaranya stres yang terjadi dalam konteks hubungan sosial. Teori klasik terkait stres yang dikemukakan oleh Selye (1950), menunjukkan bahwa fenomena stres sosial dan stres fisik pada umumnya terjadi melalui tahapan yang relatif sama, yang kemudian disebut sebagai General Adaptation Syndrome.

Lebih lanjut, Social Neuroscience merupakan persilangan antara cabang displin Neuroscience, ilmu kognitif, dan ilmu sosial (Cacioppo, dkk., 2002). Peneliti di bidang Social Neuroscience umumnya adalah mereka yang menekuni ilmu kognitif, dan kemudian tergerak untuk mengkaji fenomena sosial mengingat bahwa manusia pada dasarnya adalah makhluk sosial. Sementara kajian dengan pendekatan objektif dan fisiologis pada perilaku kognitif manusia sudah banyak ditemukan, misalnya terkait atensi (Compton, 2003), memori (Milner, Squire, \& Kandel, 1998), persepsi visual (Tong, 2003), masih sedikit pembahasan dengan level keilmiahan yang setara pada konteks perilaku sosial seperti misal nya: perilaku kolaborasi, kompetisi, agresivitas, prososial, empat, komunikasi, keterlibatan, keterikatan sosial, dan masih banyak lagi. Kekhawatiran itu yang kemudian melandasi lahirnya penelitian-penelitian dalam ranah Social Neuroscience (Rozin, 2001).

Menariknya, penelitian Social Neuroscience tidak hanya membatasi kajian pada subjek manusia, tetapi juga beberapa spesies hewan tertentu yang diduga memiliki level kognitif tinggi, misalnya primata (Saxe, 2006). Hal ini didasari temuan bahwa beberapa primata menunjukkan kapasitas kognitifyang dimiliki oleh manusia, seperti misalnya kemampuan numerik (Cantlon \& Brannon, 2006), bahasa (Benson, Greaves, O'Donnell, \& Taglialatela, 2002), dan pengambilan keputusan (Shadlen \& Newsome, 2001). Bahkan penelitian terkait mirror neuron yang akhir-akhir ini diduga memiliki implikasi pada empati manusia, pertama kali ditemukan melalui studi dengan subjek primata (Penjelasan lebih lanjut, baca Rizzolatti \& Craighero, 2004). Atau bagaimana dengan spesien ikan hias yang bisa mengenali wajah pemiliknya sebagaimana ditemukan oleh Newport, Wallis, Reshitnyk, dan Siebeck (2016)?

Lebih lanjut lagi, literatur-literatur terdahulu menemukan analogi antara bagian otak manusia dengan beberapa spesies hewan (Herculano-Houzel, 2009; Mantini, Corbetta, Romani, Orban, \& Vanduffel, 2012) yang memungkinkan penelitian dengan objek hewan digunakan sebagai proxy dalam memahami mekanisme neural manusia. Namun demikian, peneliti- 
peneliti tersebut menyadari bahwa kehidupan manusia jauh lebih kompleks daripada hewan, sehingga validasi lebih lanjut diperlukan supaya penelitian-penelitian tersebut dapat secara akurat memprediksi perilaku manusia.

Keterlibatan subjek hewan dalam penelitian Social Neuroscience memiliki arti penting karena penelitian dengan subjek manusia memiliki keterbatasan, yang tertuang dalam kode etik penelitian khususnya dalam bidang Neuroscience (Illes \& Bird, 2006). Terdapat setidaknya empat prinsip utama etika penelitian yang harus ditegakkan dalam pendekatan ini (Fukushi, Sakura, \& Koizumi, 2007), yaitu: (i) autonomy (keputusan yang diambil oleh subjek penelitian untuk terlibat berdasarkan atas kesadaran diri sendiri tanpa adanya paksaan), (ii) non-maleficence (minimnya resiko dan bahaya yang ditimbulkan dari prosedur penelitian), (iii) beneficence (adanya keuntungan pribadi yang akan didapat oleh partisipan, seperti misalnya kondisi kesehatan yang membaik), dan (iv) justice (keterbukaan terhadap keuntungan, resiko, dan konsekuensi lain yang ditimbulkan). Penelitian dengan metode invasive (yaitu melibatkan aktivitas memasukkan sensor/ instrumen ke dalam struktur jaringan syaraf) pada manusia, terutama pada populasi manusia yang sehat jelas tidak mungkin dilakukan karena melanggar prinsip non-maleficence dan beneficence. Hal ini yang menyebabkan keterbatasan penelitian seluler dan molekuler dilakukan pada manusia. Kecuali jika partisipan penelitian merupakan pasien yang sudah terlanjur mengalami kerusakan (lesion) pada bagian sistem syaraf tertentu.

Menariknya, beberapa jenis penelitian Social Neuroscience terbaru dengan subjek manusia justru mengadopsi perilaku alami yang ditunjukkan oleh spesies hewan. Seperti misalnya penelitian Boos, Pritz, Lange, dan Belz (2014) yang meniru perilaku sekawanan burung yang terbang berkelompok (dalam rangka migrasi) untuk meneliti fenomena kepemimpinan pada manusia. Lebih lanjut lagi, peneliti merancang suatu permainan komputer yang bisa dimainkan oleh banyakpemain (multi-players) secara bersamaan. Peneliti menemukan bahwa kepemilikan informasi yang bermanfaat (dalam hal ini adalah lokasi spesifik pada peta permainanyang menghasilkan banyak poin bonus) akan mampu membuat gerakan seorang individu diikuti oleh para pemain lainnya Ini menunjukkan bahwa kepemilikan terhadap informasi bisa menjadi kekuatan sosial, konsisten sebagaimana yang ditunjukkan oleh temuan penelitan ilmu sosial terdahulu (Day, 2001; Spekman, 1979).

\section{Desain Penelitian Social Neuroscience}

Salah satu kritik yang kerap dialamatkan pada pendekatan Social Neuroscience ialah mengenai karakteristik reduksionis dalam mendefinisikan variabel penelitiannya sehingga kurang bisa mencerminkan kondisi yang riil (Edwards, 2013), meski beberapa penelitian terbaru telah menggunakan pengukuran dalam situasi naturalistik (dalam perilaku alami sehari-hari), seperti misalnya dengan pendekatan Ecological Momentary Assessment sebagaimana ditunjukkan pada penelitian terkait stres (Goldschmidt, dkk., 2014; Kowalczyk, dkk, 2015), kecemasan (Tan, dkk., 2012), adiksi (Wilson, Smyth, \& MacLean, 2013), dan lain-lain. Perilaku sosial manusia merupakan suatu fenomena yang sangat kompleks dan multikontekstual. Bagaimana mungkin data fisiologis yang sederhana bisa merepresentasikan fenomena kehidupan manusia yang kompleks?

Setidaknya beberapa literatur menunjukkan bahwa terdapat beberapa proses mental manusia yang sifatnya umum dan melibatkan bagian otak yang sama, apapun konteksnya. Seperti misalnya, sebuah ulasan literatur menunjukkan bahwa area lateral intraparietal (LIP) pada manusia terlibat dalam proses akumulasi informasi yang umum terjadi pada proses pengambilan keputusan apapun jenisnya (Gold \& Shadlen, 2007), baik itu pengambilan keputusan yang sederhana seperti misalnya dalam tugas-tugas persepsi visual maupun pengambilan keputusan sehari-hari (Sanfey, Loewenstein, McClure, \& Cohen, 2006). Lazim dalam penelitian Neuroscience, ditemukan beberapa bagian otak yang aktif secara bersamaan ketika mengerjakan suatu tugas yang spesifik. Bagian-bagian otak ini biasanya terkait dengan konteks atau karakteristik yang menempel pada jenis tugas yang diberikan. Penelitian $0^{\prime}$ Craven dan Kanwisher (2000) misalnya, menemukan bahwa perilaku membayangkan (mental imagery) sebuah bangunan rumah akan mengaktifkan parahippocampal place area (PPA). Namun ketika partisipan diminta membayangkan wajah manusia, justru area fusifiorm face area (FFA) yang aktif. Dua bagian otak yang disebutkan tadi adalah area yang terlibat pada konteks tugas yang berbeda-beda (bangunan versus wajah). Menariknya, area V1 pada occipital area otak terlihat aktif saat subjek membayangkan wajah atau bangunan. Area yang disebut terakhir inilah yang kemudian disebut sebagai area otak yang bertanggung jawab atau generator utama pada proses mental imagery manusia.

Terkait dengan hal ini, diperlukan kejelian dalam merancang desain penelitian agar terhindar dari interpretasi yang tidak akurat. Reduksionisme dalam desain penelitian Social Neuroscience penting dilakukan karena tanpanya akan terjadi multitafsir interpretasi data fisiologis yang didapatkan (Edwards, 2013). Penelitian Goldberg, Harner, Lovell, Podell, dan Riggio (1994) misalnya, menunjukkan adanya pengaruh jenis kelamin dan dominasi tangan (handedness) pada tugas kognitif, yang kemudian disebut sebagai bias gender. Hal ini berimplikasi pada kriteria pemilihan partisipan penelitian yang ketat. Lazim dalam penelitian Neuroscience untuk hanya melibatkan kelompok populasi tertentu, misalnya hanya yang berjenis laki-laki atau yang dominan tangan kanan. Perbedaan jenis kelamin dan handedness akan berpengaruh pada struktur anatomi otak yang sedikit berbeda, sehingga diduga akan memberikan data fisiologis yang bervariasi. Secara umum, peneliti seyogianya mampu memijahkan variabel psikologis 
yang akan diteliti dari variabel pencemar yang mungkin berpengaruh sehingga benar-benar yakin bahwa data fisologis yang didapatkan merepresentasikan variabel yang menjadi tujuan penelitian.

Terkait dengan isu di atas, penelitian eksperimen yang dilakukan oleh tim Laboratorium Mind, Brain, \& Behaviour, Fakultas Psikologi Universitas Gadjah Mada, yaitu Jamaluddin, Adi, dan Lufityanto (2020) mengenai pengaruh kolaborasi dalam perilaku curang telah diarahkan untuk membangun peta riset dengan pendekatan Social Neuroscience. Meskipun penelitian ini masih berfokus pada pengembangan paradigma penelitian yang objektif dan terukur secara behavioral dalam memahami perilaku sosial, ke depannya penelitian serupa bisa dikembangkan lagi dengan pengukuran mekanisme neural sebagaimana yang diharapkan dalam penelitian-penelitian pendekatan Social Neuroscience. Lebih lanjut lagi, penelitian ini menemukan bahwa partisipan yang memiliki orientasi nilai kolektivistik akan berperilaku curang bilamana lingkungan sosialnya mendukung perilaku tersebut. Tantangan dalam penelitian itu adalah bagaimana cara mendefinisikan perilaku curang dan bagaimana cara mengukur perilaku curang tanpa terdeteksi oleh partisipan penelitian. Dengan menggunakan metode lempar dadu secara berpasangan, yang diperkenalkan oleh Weisel dan Shalvi (2015), partisipan tidak akan menyangka bahwa tugas melempar dadu dan mengetikkan hasilnya di layar komputer (di dalam ruangan tertutup) tersebut bertujuan untuk mengukur perilaku curang. Perilaku curang ditentukan dari rasio simpangan skor dadu yang dilaporkan (empirik) terhadap probabilitas idealistik dadu yang akan muncul secara hipotetik. Diketahui bahwa mean skor dadu adalah 3,5 (mean hipotetik). Ini berarti ada indikasi keanehan apabila seorang individu melaporkan mean empirik yang sangat menyimpang dari mean hipotetik tersebut. Dalam penelitian Jamaluddin, Adi, dan Lufityanto (2020), para partisipan diberi tahu bahwa jika mereka beruntung untuk mendapatkan skor dadu tinggi (yaitu: 4, 5, atau 6) maka mereka berpotensi mendapatkan imbalan/kompensasi uang yang lebih tinggi. Hasilnya, partisipan menunjukkan perilaku melaporkan angka dadu tinggi jauh di atas standar deviasi hipotetik (mean+1SD), yang mengindikasikan terjadi kecurangan. Menariknya, perilaku curang ini tidak ditunjukkan pada tugas mandiri, tetapi tampak jelas pada tugas berpasangan khususnya ketika pasangan mainnya terang-terangan berbuat curang (melaporkan skor dadu tinggi pula). Skor dadu tinggi yang dihasilkan oleh pasangan mainnya seakan memberikan sinyal/pertanda bagi partisipan untuk berperilaku curang.

Penelitian di atas tidak lantas berhenti begitu saja. Setelah dilakukan beberapa kali replikasi dan menghasilkan efek yang sama, Jamaluddin, Adi, dan Lufityanto (2020) melakukan studi lanjutan untuk melihat apakah terdapat hubungan langsung antara tingkat kecurangan pasangan dengan tingkat kecurangan partisipan penelitian. Dalam ilmu perilaku, jika kita mampu menampilkan fungsi linear antara dua variabel, maka semakin kuatlah argumen kita bahwa kedua variabel tersebut saling berkorelasi (Byrne \& Nelson, 1965; de la Fuente, dkk., 2017; Locke, 1965). Temuan Jamaluddin, Adi, dan Lufityanto (2020) ini menunjukkan bahwa semakin besar skor dadu yang dilaporkan oleh pasangan, semakin besar pula skor yang dilaporkan oleh partisipan. Sebaliknya, semakin kecil skor dadu yang dilaporkan oleh pasangan mainnya, semakin kecil pula lah skor dadu yang dilaporkan oleh partisipan. Hal ini menarik, karena setidaknya penelitian ini menunjukkan bahwa kecurangan tidak sematamata disebabkan karena intensi untuk mencari keuntungan finansial saja, tetapi juga karena faktor lingkungan sosial.

Penelitian Social Neuroscience bukan berarti mengharuskan penggunaan metode eksperimen. Sebagaimana terlihat dalam Tabel Lampiran 1, beberapa penelitian Social Neuroscience menggunakan metode korelasional. Namun demikian, salah satu kelebihan dari pendekatan eksperimenadalahfleksibilitas yang dimiliki untuk mengubah dan menyesuaikan parameter dalam penelitian agar sejalan dengan apa yang terjadi dalam konteks yang nyata. Ketika apa yang terlihat di konteks nyata bisa divalidasi dalam penelitian laboratorium, kita menjadi semakin yakin bahwa paradigma penelitian yang reduksionis ini tetap mampu merepresentasikan kondisiyang riil.

Masih dengan contoh penelitian kecurangan kolaboratif di atas, tim peneliti kemudian memunculkan pertanyaan baru: apakah jika jumlah imbalan uang ditambah maka akan mengubah hasil penelitian, misalnya partisipan akan curang pada tugas mandiri, namun tidak dalam tugas berpasangan? Kusuma dan Lufityanto (2019) mereplikasi penelitian di atas dengan menambah nominal imbalan bagi partisipan tiap kali melaporkan skor dadu yang tinggi. Guna mendapatkan informasi nominal imbalan yang sesuai, peneliti tersebut melakukan survei awal terkait nominal pengeluaran harian mereka. Temuan penelitian ini selanjutnya menunjukkan bahwa dengan imbalan uang yang besarannya signifikan bagi partisipan, perilaku curang juga ditunjukkan dalam tugas mandiri. Namun, perilaku kecurangan masih lebih tinggi pada tugas berpasangan. Hal ini mengindikasikan bahwa motivasi pribadi untuk mencari keuntungan dengan cara berbuat curang tidak lantas memadamkan kecenderungan untuk berbuat curang dalam setting kolaboratif. Justru adanya studi lanjut ini semakin memperkuatargumen peneliti tentang efek kolaborasi terhadap perilaku curang pada konteks masyarakat kolektif.

Parameter perilaku yang objektif, satuannya jelas, dan bisa dikendalikan merupakan kelebihan dalam penelitian Social Neuroscience. Desain penelitian seperti ini membutuhkan validasi dan replikasi berulang kali, terkadang dengan mengubah parameter penelitian, sebelum akhirnya dilakukan pengukuran yang bersifat fisiologis. Beberapa penelitian Neuroscience terkait perilaku curang pernah dilakukan oleh para peneliti sebelumnya 
(Untuk keterangan lebih lanjut, baca Abe, 2009), yang mengindikasikan area otak di bagian prefrontal cortex terlibat dalam perilaku kecurangan. Lebih spesifik lagi, dorsolateral lateral prefrontal cortex sering dihubungkan dengan intensi untuk berperilaku curang Hal ini diperkuat lagi oleh penelitian lain yang menunjukkan bahwa perilaku curang dan berbohong membutuhkan kemampuan kognitif yang tinggi, dikarenakan individu harus merancang skenario palsu yang bisa dipercaya, ketimbang mengatakan hal yang sesungguhnya (Greene \& Paxton, 2009). Namun, penelitian terkait kecurangan kolaboratif belum pernah memasuki level pengukuran fisiologis, sehingga desain penelitian kecurangan kolaboratif yang dilakukan oleh tim peneliti Laboratorium Mind, Brain, \& Behaviour di atas sangat mungkin dikembangkan ke arah pengukuran fisiologis, dengan menggunakan referensi pengukuran fisiologis yang sudah ada.

\section{Metode Pengukuran dalam Social Neuroscience}

Penelitian terdahulu telah menunjukkan bermacammacam metode yang bisa digunakan dalam mengumpulkan data fisiologis (Lihat Lampiran 1), mulai dari pengumpulan sampel data biologis hingga melakukan intervensi medis/biologis. Metode analisis korelasional umumnya dilakukan dalam penelitian genetik atau penelitian dengan subjek manusia yang salah satu bagian otaknya mengalami kerusakan. Misalnya pada penelitian Fresan, dkk. (2007) yang dilakukan dengan cara mengambil sampel darah dari penderita skizofrenia untuk kemudian diekstraksi sel-sel genetiknya. Pengambilan sampel darah untuk analisis merupakan salah satu prosedur standar dalam penelitian genetik (Ghatak, Muthukumaran, \& Nachimuthu, 2013). Selanjutnya, Fresan, dkk. (2007) melakukan uji korelasi antara frekuensi genotipe/alel pada gen DRD4 dan MAO-A dengan skor pada skala agresivitas pasien skizofrenia, dan ditemukan bahwa mutasi dua gen di atas berkorelasi dengan perilaku agresivitas pada sampel penelitian ini.

Metode penelitiangenetik pada subjek hewan lebih bervariasi lagi. Hal ini disebabkan karena karakteristik penelitiannya yang memperbolehkan peneliti melakukan intervensi biologis/medis langsung dan invasif, tidak seperti pada subjek manusia. Prosedur seperti knockout mice, sering dilakukan pada penelitian Neuroscience (Crawley, 2007). Prosedur knockout mice pada dasarnya merupakan pendekatan yang memanfaatkan teknologi transgenik dengan kombinasi antara pendekatan manipulasi genetik in vitro (atau pengembangan dalam wadah lain, tidak secara alami, contoh: bayi tabung) dan analisis biologis in vivo (dikembangkan dalam organ makhluk hidup secara alami). Proses ini dimulai dengan menciptakan serum untuk menekan ekspresi genetik yang menjadi target penelitian. Langkah selanjutnya adalah melakukan injeksi pada tubuh tikus sehingga nantinya akan melahirkan keturunan yang tidak memiliki gen target (Fässler, Martin, Forsberg, Litzenbarger, \& Iglesias, 1995). Keturunan tikus inilah yang nanti akan menjadi subjek dalam penelitian dengan pendekatan ini.

Uraian di bawah ini akan lebih menekankan pada metode pengambilan data yang lazim dilakukan pada subjek manusia terkait dengan mekanisme neural. Penelitian seperti ini lebih memungkinkan untuk dilakukan dalam setting Psikologi, karena relatif tidak menuntut kemampuan medis tingkat tinggi (dibandingkan dengan studi genetik, misalnya). Ketika kita ingin mengetahui bagian otak mana yang berpengaruh pada suatu perilaku spesifik, setidaknya terdapat tiga macam kategori pengumpulan data yang lazim dilakukan dalam penelitian Social Neuroscience, yaitu: (i) pemindaian/perekaman otak, (ii) stimulasi non-invasif pada otak, dan (iii) pengukuran syaraf perifer/tepi. Gambar 1 mengilustrasikan instrumen yang mewakili masing-masing teknik pengambilan data.

Perlu diperhatikan bahwa masih banyak instrumen yang tidak disebutkan dalam artikel ini, seperti misalnya magnetic resonance imaging (MRI) yang umumnya digunakan untuk meneliti struktur sistem syaraf atau struktur fisiologis manusia lainnya. Dikarenakan fokus dari kajian Social Neuroscience adalah perilaku, maka analisis fungsional otak lebih sering digunakan daripada anal isis struktural, sehingga peneliti Social Neuroscience lebih cenderung memilih menggunakan functional magnetic resonance imaging (fMRI) daripada mesin MRI atau diffusion tensor imaging (DTI) - yang secara spesifik digunakan untuk mengkaji komponen pembentuk otak. Beberapa alat lain seperti misalnya near-infrared reflectance spectroscopy (NIRS) juga banyak digunakan sebagai alternatif pengganti fMRI. Namun demikian, studi terbaru menunjukkan kelebihan fMRI dalam analisis antar kelompok (Minati, Visani, Dowell, Medford, \& Critchley, 2011), dikarenakan variasi yang dihasilkan dari pengukuran menggunakan fMRI tidak sebesar NIRS. 


\section{Gambar 1}

Teknik Pengukuran Neuralyang Lazim Dilakukan dalam Penelitian Social Neuroscience Beserta Contoh Instrumen yang Digunakan.

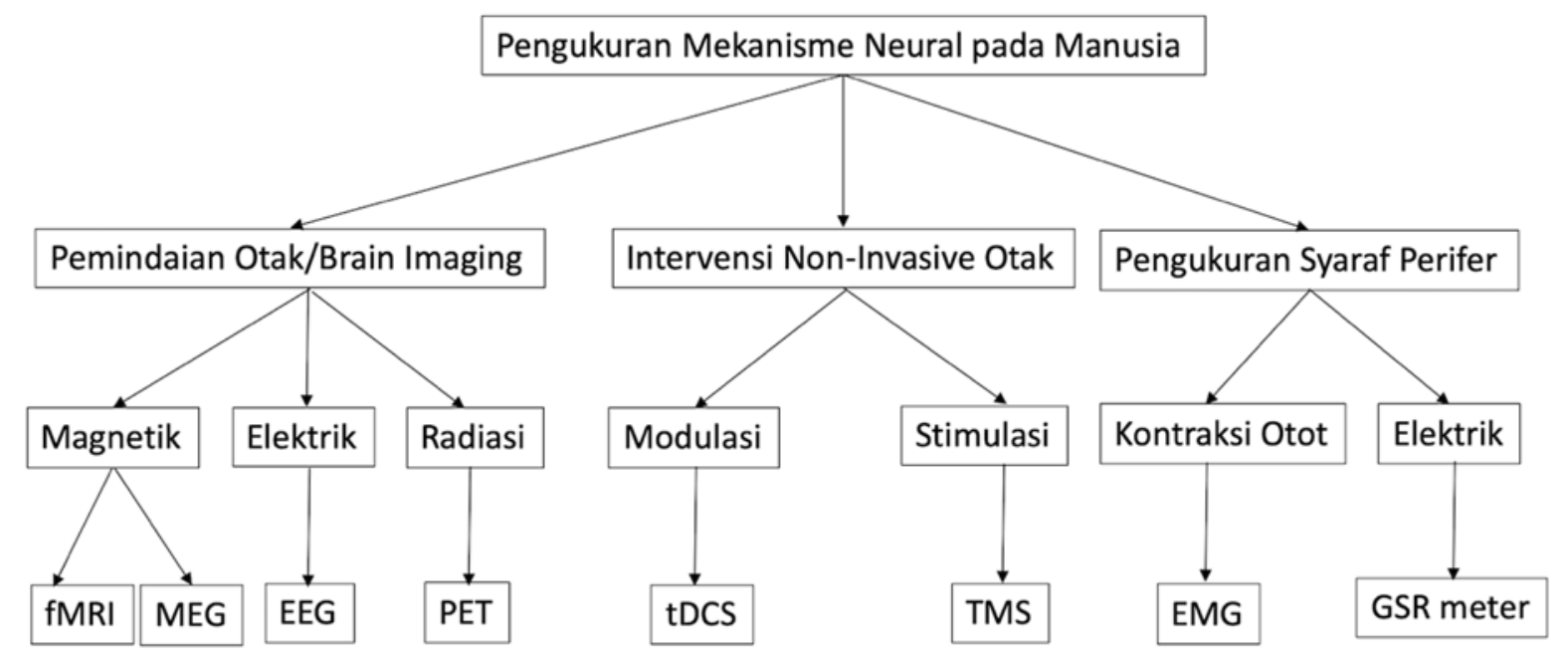

\section{Teknik Pemindaian/Perekaman Otak (Brain Imaging)}

Teknik pengukuran ini termasuk yang paling populer digunakan dalam studi Neuroscience. Di antara instrumen yang mengaplikasikan teknik ini, fMRI tetap menjadi primadona (Papadelis, Grant, Okada, \& Preissl, 2015). Lebih lanjut lagi fMRI telah banyak digunakan untuk mengukur beberapa fenomena dalam perilaku sosial, seperti misalnya: fobia sosial (Lorberbaum, dkk., 2004), interaksi sosial (Dumas, Nadel, Soussignan, Martinerie, \& Garnero, 2010; Iacoboni, dkk., 2004), empati (Akitsuki \& Decety, 2009), kompetisi dan kolaborasi (Decety, Jackson, Sommerville, Chaminade, \& Meltzoff, 2004), dan masih banyak lagi. Meskipun kelebihannya tidak diragukan lagi, fMRI masih menjadi momok bagi para peneliti ilmu sosial (Huettel, dkk., 2009) dikarenakan kompleksitas cara kerjanya membutuhkan komitmen waktu dan usaha keras untuk menguasainya (Song, Huettel, \& McCarthy, 2006). Namun, Dimoka (2012) telah menunjukkan bagaimana prosedur penggunaan fMRI yang sederhana bagi para peneliti ilmu sosial. Pada prinsipnya, terdapat empat langkah dalam mengaplikasikan teknik ini, yaitu: (i) memformulasikan pertanyaan penelitian, (ii) merancang protokol penelitian dengan mempertimbangkan karakteristik mesin fMRI, (iii) menganalisis data fMRI, dan (iv) menginterpretasi serta melaporkan data fMRI. Dengan memahami empat tahapan tersebut, maka peneliti ilmu sosial bisa mengalokasikan waktu dan tenaga untuk menguasai semua tahapan sehingga berdiri menjadi peneliti Social Neuroscience yang mandiri atau alih-al ih melakukan langkah kolaborasi dengan peneliti lain yang mendalami teknik pengukuran dan analisis fMRI. Jika opsi kolaborasi yang diambil, maka peneliti ilmu sosial seyogianya juga membekali diri dengan kemampuan untuk memformulasikan pertanyaan penelitian dan merancang protokol penelitian yang sesuai dengan pendekatan penelitian Social Neuroscience.

Keempat prosedur itu relatif berlaku untuk semua teknik penginderaan otak, apapun instrumen yang digunakan. Perbedaan antara satu instrumen dengan instrumen lainnya adalah media yang digunakan (magnetik, elektrik, atau radiasi) dan jenis informasi apa yang dibutuhkan untuk menjawab pertanyaan penelitian (spatial/lokasi otak yang spesifik atau temporal/waktu pemrosesan di dalam otak). fMRI banyak digunakan oleh peneliti karena akurasinya dalam menunjukkan lokasi/spatial otak yang spesifik (Dimoka, 2012; Goense, Bohraus, \& Logothetis, 2016; Triantafyllou, Hoge, \& Wald, 2006). Dengan memanfaatkan partikel magnetik yang terkandung dalam sel darah, fMRI mampu untuk secara akurat menunjukkan lokasi otak yang teraktivasi, yaitu dengan cara mendeteksi perubahan oksigenasi pada aliran darah di bagian otak tersebut. Parameter yang diukur dalam fMRI adalah blood oxygen level dependent atau sering disebut sebagai BOLD. Otak yang aktif akan menunjukkan kadar deoksigenisasi yang tinggi. Proses ini akan bisa dideteksi oleh sensor magnetik pada mesin fMRI (Logothetis, Pauls, Augath, Trinath, \& Oeltermann, 2001).

Masih sejalan dengan cara kerja fMRI, magnetoencephalograpgy (MEG) juga menggunakan cara kerja magnetik untuk mendeteksi aktivitas otak yang spesifik (Wheless, dkk., 2004). Namun, berbeda dengan fMRI yang mengidentifikasi perubahan kadar oksigenisasi darah pada otak, MEG mendeteksi perubahan aktivitas magnetik pada otak yang muncul akibataliran listrik yang terjadi antar sel neuron otak (Hansen, Kringelbach, \& Salmelin, 2010; PascualMarqui, Michel, \& Lehmann, 1994). Aliran listrik antar neuron ini umum terjadi ketika bagian otak tersebut aktif (Gazzaniga, 2014; Purpura \& McMurtry, 1965). 
Dengan demikian, perubahan aktivitas magnetik secara otomatis menandakan pula terjadinya aktivitas otak. MEG sudah lama digunakan dalam banyak penelitian, misalnya: penyakit neurodegeneratif seperti Parkinson atau Alzheimer (Stam, 2010), kemampuan berbahasa (Embick, Hackl, Schaeffer, Kelepir, \& Marantz, 2001), dan masih banyak lagi. Dalam penelitian dengan pendekatan Social Neuroscience, MEG sudah dimanfaatkan untuk meneliti proses kognitif dalam percakapan antara dua orang (Baess, dkk., 2012) dan interaksi sosial yang sifatnya lebih umum (Pavlova, Guerreschi, Lutzenberger, Sokolov, \& Krägeloh-Mann, 2010).

Electroenchepalogram (EEG) merupakan instrumen yang juga cukup populer digunakan dalam penelitian. Instrumen ini cukup ekonomis apabila dibandingkan dengan dua alat yang telah disebutkan sebelumnya. EEG lazim dipakai untuk mendeteksi aktivitas elektrik di bagian permukaan otak manusia alias bagian korteks (Teplan, 2002). Selanjutnya, dengan metode Fourier Transform, sinyal mentah EEG tersebut akan diubah menjadi gelombang otak, yang diklasifikasikan menjadi (i) gamma ( $>30 \mathrm{~Hz}$ ), (ii) beta (14-30Hz), (iii) alpha $(9-13 \mathrm{~Hz})$, (iv) theta $(4-8 \mathrm{~Hz})$, dan (v) delta $(0,5-4 \mathrm{~Hz})$ (Henry, 2006). Masing-masing jenis gelombang otak tersebut menandakan level kesadaran manusia dan perilaku yang dihasilkan (Alkire, Hudetz, \& Tononi, 2008; Boly, dkk., 2008). Meskipun EEG memiliki kelemahan dalam resolusi spasial (lokasi), tetapi instrument ini unggul dalam resolusi temporal atau waktu (Freeman \& Rogers, 2002). Bahkan resolusi spasial EEG mengalahkan instrumen fMRI dan MEG, sehingga peneliti kerap menggunakan EEG untuk mengidentifikasi proses kognitif yang terkait erat dengan waktu, misalnya pemrosesan semantik (Klimesch, Schimke, \& Schwaiger, 1994) atau sintaksis (Bastiaansen, Van Berkum, \& Hagoort, 2002) dalam bahasa.

Instrumen selanjutnya, positron emission tomography (PET) menggunakan senyawa kimia yang bisa dideteksi oleh sensor radioaktif (atau disebut sebagai radiotracer). Penelitian ini melibatkan injeksi senyawa radiokatif yang diberi nama [18F]-fluorodeoxyglucose atau sering diistilahkan sebagai FDG (Di Chiro, dkk., 1982) ke dalam tubuh manusia (Bailey, Maisey, Townsend, \& Valk, 2005). Ketika sel otak teraktivasi, maka area tersebut akan mengonsumsi energi tambahan. FDG yang memiliki el emen glukosa akan diserap oleh bagian otak tersebut. Salah satu penelitian Social Neuroscience yang menggunakan metode ini ialah penelitian terkait kecemasan sosial (Frick, dkk., 2015) yang melihat proses sintesis hormon serotonin. Kekurangan hormon serotonin dalam tubuh manusia diduga bisa menyebabkan kecemasan sosial (Lanzenberger, dkk., 2007). Namun, setelah kemunculan fMRI, popularitas pengukuran menggunakan PET terutama karena ada indikasi bahwa pemindaian seluruh tubuh (whole-scanning) PET yang dilakukan berulang akan berpotensi menambah dosis reaksi radioaktif yang akan turut meningkatkan resiko kanker (Huang, Law, \& Khong, 2009).

\section{Intervensi Non-Invasif Otak}

Selain menggunakan teknik pemindaian otak, salah satu alternatif cara yang bisa dilakukan untuk menemukan hubungan kausalitas antara aktivitas bagian otak tertentu dengan suatu perilaku yang spesifik adal ah dengan menggunakan intervensi non-invasif (tanpa memasukkan sensor ke dalam jaringan syaraf manusia), baik itu yang sifatnya modulasi maupun stimulasi. Dikatakan modulasi karena teknik ini tidak secara akurat memengaruhi bagian otak tertentu secara spesifik, alih-alih mempengaruhi satu area atau jaringan syaraf dalam otak (Brunoni, dkk., 2012), misalnya: jaringan prefrontal cortex. Salah satu instrumen yang paling sering digunakan dalam teknik ini adalah transcranial direct-current stimulation (tDCS). tDCS memanfaatkan arus listrik rendah, tidak lebih dari 2,5 miliAmper untuk mempengaruhi area otak atau jaringan syaraf tertentu (Nitsche, dkk., 2008). Instrumen ini telah mendapatkan sertifikasi (penggunaan untuk riset pada umumnya, dan beberapa jenis terapi) dari beberapa lembaga penjamin instrumen dan protokol medis dunia seperti misalnya Food and Drugs Administration di Amerika, Australian Therapeutic Goods Administration di Australia, Comité de Protection de Personnes (CPP) di Perancis, dan lainlain (Untuk keterangan lebih lanjut, baca Fregni, dkk, 2015).

Prosedur penelitian menggunakan tDCS cukup sederhana, yaitu menempelkan dua pelat elektroda pada kulit kepala. Salah satu elektroda, disebut sebagai anodal, sedangkan elektroda satunya disebut sebagai katodal (Stagg \& Nitsche, 2011). Aliran listrik yang mengalir dari anodal ke katodal akan bersifat mengaktifkan bagian otak yang dilewatinya. Sebaliknya, aliran yang mengalir dari katodal ke anodal akan bersifat menghambat (inhibisi). Dengan cara itu, peneliti dapat melakukan manipulasi aktivasi dan inhibisi sekaligus pada bagian otak yang sama. Salah satu penelitian yang menggunakan metode ini adalah penelitian Jacobson, Javitt, dan Lavidor (2011) terkait perilaku impulsif. Aktivasi anodal pada daerah inferior frontal gyrus di bagian kanan akan mengurangi perilaku impulsif. Sebaliknya, inhibisi katodal pada daerah yang sama akan meningkatkan perilaku impulsif.

Dibandingkan dengan teknik modulasi, teknik stimulasi otak diyakini bisa memberikan efek intervensi yang lebih akurat pada bagian otak yang spesifik, dengan tingkat ketelitian hingga satuan milimeter (Kanai, Paulus, \& Walsh, 2010). Transcranial magnetic stimulation (TMS) adalah salah satu contoh instrumen yang sering dipakai dalam penelitian, termasuk yang mengkaji fenomena sosial seperti kecurangan (Karton, Palu, Jõks, \& Bachmann, 2014). Penelitiantersebut menunjukkan bahwa mengaktifkan daerah dorsolateral prefrontal cortex (DLPFC) bagian kiri akan mengurangi perilaku curang. Sebaliknya, mengaktifkan daerah DLPFC kanan justru akan meningkatkan perilaku curang. Adapun cara kerja TMS ini adalah dengan menggunakan induksi 
magnetik pada koil logam yang diarahkan ke area otak yang dituju Induksi magnetik tersebut kemudian akan menghasilkan aliran listrik pada daerah sasaran otak, sesuai hukum Fisika Faraday (Choi, Jung, Lee, \& Cho, 2007).

TMS mengaktifkan dan menonaktifkan bagian otak tertentu dengan cara mengatur frekuensi induksi magnetik. Frekuensi rendah TMS (umumnya di bawah $1 \mathrm{~Hz}$ ) akan menghambat aktivitas otak (Muellbacher, Ziemann, Boroojerdi, \& Hallett, 2000), sedangkan frekuensi tinggi (di atas $1 \mathrm{~Hz}$, umumnya 10Hz) akan meningkatkan aktivitas otak (Guse, Falkai, \& Wobrock, 2010). Metode ini memungkinkan peneliti untuk menyesuaikan paradigma penelitian sesuai dengan kebutuhan sehingga mampu menguji hubungan kausalitas antara aktivitas bagian otak tertentu dengan perilaku yang spesifik.

\section{Teknik PengukuranSyaraf Perifer/Tepi}

Karena teknik penginderaan otak dan intervensi non-invasif otak membutuhkan biaya yang tidak sedikit, terutama untuk pengadaan instrumen tersebut, maka peneliti Social Neuroscience terkadang menggunakan teknik terakhir yaitu pengukuran syaraf perifer/tepi. Pengukuran ini umumnya menyasar jaringan syaraf eferen dan syaraf otonomik (autonomous nervous system/ANS). Syaraf eferen merupakan jaringan yang membawa impuls motorik dari sistem syaraf pusat (otak dan tulang belakang) menuju organ tubuh/efektor(Burg, Szumski, Struppler, \& Velho, 1973). Gerakan tubuh, bahkan hanya yang berupa kontraksi otot halus, bisa digunakan sebagai referensi proses mental manusia, misalnya: emosi yang terjadi tanpa disadari (Wexler, Warrenburg, Schwartz, \&Janer, 1992). Pada penelitian ini, partisipan diperdengarkan kata-kata dalam durasi waktu yang singkat. Electromyogram (EMG), sebagai salah satu instrumen yang memanfaatkan teknik ini, dipasangkan pada otot corrugator (di dekat kelopak mata) dan zygomatic (di dekat pipi menuju bibir) di area wajah. EMG yang mampu mendeteksi kontraksi otot halus pada wajah tersebut bahkan diduga dapat membedakan jenis ekspresi emosional tertentu.

Instrumen EMG memiliki beberapa elektroda yang dipasangkan di area otot yang diprediksi akan mengalami kontraksi apabila suatu stimulus diberikan. Peneliti seyogianya memilih jaringan otot halus yang sensitif terhadap rangsangan sebagai lokasi penempelan sensor EMG. Salah satu kelebihan dari instrumen ini ialah cara penggunaannya yang cukup sederhana, serta dapat menangkap sinyal motorik sebagai penanda emosi sementara. Karena al asan ini, EMG mulai banyak digunakan dalam kajian yang sifatnya lebih praktis, misalnya Lajante, Droulers, dan Amarantini (2017) yang meneliti respon emosi terhadap bermacam-macam bentuk iklan.

Masih terkait dengan pengukuran syaraf perifer, salah satu teknik lain yang sering digunakan oleh para peneliti adalah pengukuran galvanic conductance responses (GSR), yaitu kadar konduktivitas otak terhadap aliran listrik. Konduktivitas jaringan kulit ini tergantung pada kadar sekresi keringat (Montagu \& Coles, 1966). Literatur terdahulu telah menunjukkan bahwa jaringan syaraf otonom, yaitu simpatetik, sangat berkaitan dengan produksi keringat di kulit (Gazzaniga, 2014). Ketika individu dalam kondisi siaga atau emosional, syaraf otonom simpatetiknya akan lebih teraktivasi sehingga akan memproduksi banyak keringat. Telah banyak penelitian yang memanfaatkan teknik ini, seperti terkait pengambilan keputusan (Naqvi \& Bechara, 2006), kesadaran (Dawson, Rissling, Schell, \& Wilcox, 2007), intuisi (Lufityanto, Donkin, \& Pearson, 2016), dan masih banyak lagi.

Dari bermacam-macam variasi GSR, yang paling sering diukur dalam penelitian adalah skin conductance response, yaitu seberapa efektif kulit kita dalam menghantarkan listrik yang dialirkan oleh GSR meter (Boucsein, 2012). Semakin efektif kulit kita dalam menghantarkan aliran listrik, menandakan semakin banyak sekresi keringat yang diproduksi, dan hal ini merupakan prediktor dari proses emosional yang tengah terjadi. GSR meter biasanya menggunakan aliran listrik yang sangat kecil, yaitu $0,5 \mathrm{~V}$, yang dialirkan antara dua elektroda yang dipasang di permukaan kulit (umumnya pada kulit jari tangan non-dominan). Partisipan umumnya tidak dapat merasakan aliran listrik ini sehingga prosedur ini sangat aman untuk dilakukan pada subjek manusia.

\section{Validasi Pengukuran Fisiologis dalam Social Neuroscience}

Penelitian Social Neuroscience tidak hanya berhenti pada pengukuran fisiologis saja. Seperti telah dikemukakan di bagian awal, bahwa pendekatan Neuroscience yang cenderung reduksionis cenderung menafikan konteks sosial yang melingkupi proses mental manusia. Oleh karenanya, langkah validasi seyogianya dilakukan untuk memperkuat inferensi data fisiologis terhadap variabel penelitian yang kompleks.

Dikarenakan studi tentang Social Cognition bermuara pada persepsi individu terhadap suatu konstruk dan fenomena sosial (Rozin, 2001; Higgins, 2000), maka metode validasi dapat dilakukan dengan cara mengumpulkan persepsi subjektif partisipan terhadap prosedur penelitian. Prosedur seperti cek manipulasi yang dilakukan dalam penelitian eksperimen (Kantowitz, Roediger III, \& Elmes, 2014; Kidd, 1976) bisa juga dilakukan, tetapi tidak jarang penelitian melibatkan pertanyaan langsung. Seperti dalam penelitian Lamm, Batson, dan Decety (2007) terkait perasaan empati pada orang lain. Dalam penelitian tersebut, partisipan diperlihatkan beberapa video klip tentang pasien yang sedang menjalani perawatan. Partisipan kemudian diinstruksikan untuk mencoba: (i) membayangkan perasaan pasien (kondisi simpati) dan (ii) membayangkan dirinya menjadi pasien (kondisi empati). Ditemukan perubahan aktivitas otak di area insular cortex, anterior median cingulate cortex (aMCC), amygdala, dan visual cortex 
antara dua kondisi perlakuan tersebut. Guna memvalidasi, pada akhir setiap tugas membayangkan partisipan diminta untuk menentukan tingkat kesakitan yang dirasakan pasien dalam skala 7-poin Likert. Analisis tambahan menunjukkan bahwa semakin tinggi tingkat kesakitan yang dibayangkan oleh partisipan, semakin tinggi pula aktivitas otak yang menandakan perasaan empati.

Sama halnya dengan penelitian yang dilakukan oleh Wu, Leliveld, dan Zhou (2011) terkait persepsi keadilan dalam konteks interaksi sosial. Peneliti ters ebut menggunakan EEG untuk mendeteksi onset proses mental saat partisipan diperlakukan tidak adil oleh pasangannya ketika bermain dictator game dalam program komputer. Ditemukan bahwa fenomena medial frontal negativity, atau aktivitas otak di bagian medial prefrontal cortex yang umum terjadi ketika individu mendeteksi adanya kesalahan (Stemmer, Segalowitz, Witzke, \& Schönle, 2004) dan harapan yang tidak terwujud/expectancy violation (Sun \& Yu, 2014), ditemukan pada kondisi ketika partisipan mendapatkan perlakuan tidak adil dari pasangan mainnya dalam penelitian $\mathrm{Wu}$, Leliveld, dan Zhou (2011) tersebut. Untuk memvalidasi data fisiologis terhadap konteks penelitian tersebut, peneliti memberikan kuesioner kepada partisipannya untuk mengevaluasi seberapa tingkat kepercayaan pasangannya tersebut.

\section{Social Neuroscience dan Aplikasinya di Indonesia}

Menilik dari paparan bukti dan rekam jejak penelitian yang telah dilakukan, pendekatan Social Neuroscience memiliki potensi yang sangat besar untuk dilakukan di Indonesia. Indonesia sebagai salah satu negara dengan populasi penduduk terbesar dan beragam di dunia (Ju Lan, 2011; Trisia, Osozawa, \& Bai, 2016) tak ubahnya laboratorium psikologi terbesar di dunia. Namun demikian, Indonesia hanya akan selalu menjadi objek penelitian, bukannya pemain utama dalam penelitian dalam topik Psikologi Sosial jika para peneliti Psikologi Sosial di Indonesia tidak segera bergegas untuk mempelajari metodologi penelitian yang menjadi state-of-the-art negaranegara yang menjadi kiblat perkembangan Ilmu Psikologi. Beberapa penelitian psikologi yang menggunakan pengukuran fisologis, meski tidak spesifik terkait tema Social Neuroscience telah dimulai di Indonesia (Lufityanto, Rahapsari, \& Kamal, 2020; Seloni, 2018; Zahrani \& Lufityanto, 2019) sehingga masa depan pemanfaatan metode ini cukup menjanjikan bagi ilmuwan di Indonesia.

Pendekatan Social Neuroscience memungkinkan sinergi antara keunikan topik sosial di Indonesia dengan metodologi yang tengah berkembang secara global. Cacioppo (2007) berargumen bahwa ke depannya Psikologi akan menjadi hub science atau ilmu yang menjadi penghubung antara kajian-kajian yang lain. Dalam artikel tersebut ditunjukkan bahwa ilmu Psikologi sangat berdekatan dengan bermacam-macam ilmu sosial, seperti misalnya pendidikan; dan juga bertetanggaan dengan ilmu biomedis. Dengan demikian, bukan mustahil apabila Social Neuroscience ke depannya menjadi tulang punggung dalam perkembangan ilmu Psikologi Sosial secara global, dan Indonesia berpotensi menjadi salah satu pemain utama.

Keyakinan ini bertolak pada kenyataan bahwa ada bermacam-macam topik penelitian Psikologi Sosial yang telah dilakukan di Indonesia, yang memungkinkan untuk dilanjutkan menjadi desain penelitian yang memfasilitasi pengukuran fisiologis. Penelitian yang dilakukan oleh Faturochman, Kurnianingsih, Kurniastuti, dan Fathoni (2011) terkait kepercayaan (trustworthiness) dalam konteks pernikahan antar suku, yang diukur menggunakan kuesioner dapat dikembangkan lebih lanjut dengan parameter penelitian fisiologis. Winston, Strange, O'Doherty, dan Dolan (2002) menggunakan fMRI menemukan bahwa respon pada skala kepercayaan ketika partisipan penelitian diminta untuk menilai gambar wajah manusia, berkorelasi dengan aktivitas di bagian otak amygdala dan insula bagian kanan. Lebih lanjut lagi Kéri dan Kiss (2011) menemukan bahwa respon kepercayaan dan keintiman berhubungan erat dengan kadar hormon oxytocin dalam tubuh.

Sementara itu penelitian Armalita dan Helmi (2018) terkait perasaan iri (envy) dalam jejaring sosial juga sangat memungkinkan untuk dirancang metode pengukuran fisologis. Dalam penelitian tersebut, partisipan disuguhkan dua skenario kesuksesan, yaitu yang dicapai dengan usaha keras dan biasa-biasa saja. Partisipan selanjutnya diberikan beberapa pertanyaan untuk mengukur (i) seberapa kuat rasa tidak suka terhadap tokoh tersebut, (ii) seberapa kuat rasa iri, dan (iii) nilai kelayakan serta kepantasan terhadap kesuksesan yang diraih tokoh tersebut. Penelitian tersebut menunjukkan bahwa perasaan iri akan muncul ketika melihat orang lain sukses dengan usaha yang biasa-biasa saja. Sejalan perasaan iri ini, penelitian Xiang, Kong, Wen, Wu, dan Mo (2016) menemukan bahwa kecenderungan untuk iri pada individu ditemukan berkorelasi dengan aktivitas inferior/middle frontal gyrus (IFG/MFG) dan dorsomedial prefrontal cortex (DMPFC). Aktivitas otak ini juga berkorelasi dengan dimensi neuroticism yang diukur menggunakan skala Revised NEO Personality Inventory (Costa Jr \& McCrae, 2008). Hal mengejutkan dalam temuan ini adalah terdapat predisposisi biologis dalam perasaan iri, yaitu mereka yang memiliki level aktivasi tinggi di daerah IFG/MFG dan DMPFC akan cenderung mudah untuk merasa iri. Dengan kata lain, perasaan iri tidak hanya merupakan fenomena yang murni bersifat sosial, namun juga dipengaruhi oleh bawaan biologis.

Pada akhirnya, perilaku manusia yang kompleks membutuhkan metodologi multilevel integratif untuk memahaminya, mulai dari level biologis hingga level sosial (Gazzaniga \& Heatherton, 2015). Heatherton (2004) berpendapat bahwa pendekatan Neuroscience dalam topikpenelitian Social 
Cognition menyajikan sudut pandang baru untuk menjawab pertanyaan yang selama ini belum pernah terjawab dalam penelitian-penelitian sosial. Perbedaan individual (individual difference) merupakan suatu pemakluman saat peneliti mendapatkan hasil yang bervariasi dalam pengukuran persepsi sosial. Perbedaan individual layaknya kepingan puzzle yang hilang, namun tak pernah secara sengaja ditemukan atau diartikan. Bisa jadi kepingan yang hilang itu adalah yang selama ini tersembunyi dalam elemen biologis - yang menunggu untuk ditemukan.

\section{Daftar Pustaka}

Abe, N. (2009). The neurobiology of deception: evidence from neuroimaging and loss-offunction studies. Current Opinion in Neurology, 22(6), 594-600.

Adolphs, R. (2001). The neurobiology of social cognition. Current Opinion in Neurobiology, 11(2),

231-239. https://doi.org/10.1016/S09594388(00)00202-6

Akitsuki, Y., \& Decety, J. (2009). Social context and perceived agency affects empathy for pain: an event-related fMRI investigation. Neuroimage, 47(2), 722-734.

Alkire, M. T., Hudetz, A. G., \& Tononi, G. (2008). Consciousness and anesthesia. Science, 322(5903), 876-880.

Alloway, T. P., \& Alloway, R. G. (2010). Investigating the predictive roles of working memory and IQ in academic attainment. Journal of Experimental Child Psychology, 106(1), 20-29.

Armalita, R., \& Helmi, A. F. (2018). Iri di Situs Jejaring Sosial: Studi tentang Teori Deservingness. Jurnal Psikologi, 45(3), 218-230.

Baess, P., Zhdanov, A., Mandel, A., Parkkonen, L, Hirvenkari, L., Mäkelä, J. P., ... Hari, R. (2012). MEG dual scanning: a procedure to study realtime auditory interaction between two persons. Frontiers in Human Neuroscience, 6, 83.

Bailey, D. L., Maisey, M. N., Townsend, D.W., \& Valk, P. E. (2005). Positron emission tomography. Springer.

Bastiaansen, M. C. M., Van Berkum, J. J. A., \& Hagoort, P. (2002). Syntactic processing modulates the $\theta$ rhythm of the human EEG. Neuroimage, 17(3), 1479-1492.

Benson, J., Greaves, W., O’Donnell, M., \& Taglialatela, J. (2002). Evidence for symbolic language processing in a bonobo (Pan paniscus). Journal of Consciousness Studies, 9(12), 33-56.

Boly, M., Phillips, C., Tshibanda, L., Vanhaudenhuyse, A., Schabus, M., Dang-Vu, T. T., ... Laureys, S. (2008). Intrinsic brain activity in altered states of consciousness: how conscious is the default mode of brain function? Annals of the New York Academy of Sciences, 1129, 119.
Boos, M., Pritz, J., Lange, S., \& Belz, M. (2014). Leadership in moving human groups. PLoS Computational Biology, 10(4), e1003541.

Boucsein, W. (2012). Electrodermal activity. Springer Science \& Business Media.

Brunoni, A. R., Nitsche, M. A., Bolognini, N., Bikson, M., Wagner, T., Merabet, L., ... Pascual-Leone, A. (2012). Clinical research with transcranial direct current stimulation (tDCS): challenges and future directions. Brain Stimulation, 5(3), 175-195.

Burg, D., Szumski, A. J., Struppler, A., \& Velho, F. (1973). Afferent and efferent activation of human muscle receptors involved in reflex and voluntary contraction. Experimental Neurology, 41(3), 754-768.

Byrne, D., \& Nelson, D. (1965). Attraction as a linear function of proportion of positive reinforcements. Journal of Personality and Social Psychology, 1(6), 659.

Cacioppo, J. (2007). Psychology is a hub science. Aps Observer, 20(8).

Cacioppo, J. T., Berntson, G. G., Adolphs, R., Carter, C. S., McClintock, M. K., Meaney, M.J., ... Taylor, S. E. (2002). Foundations in social neuroscience. MIT press.

Cantlon, J. F., \& Brannon, E. M. (2006). Shared system for ordering small and large numbers in monkeys and humans. Psychological Science, 17(5), 401-406.

Choi, K.-M., Jung, H.-J., Lee, H.-J., \& Cho, S.-W. (2007). Feasibility study of an MRdamper-based smart passive control system employing an electromagnetic induction device. Smart Materials and Structures, 16(6), 2323.

Compton, R. J. (2003). The interface between emotion and attention: A review of evidence from psychology and neuroscience. Behavioral and Cognitive Neuroscience Reviews, 2(2), 115129.

Costa Jr, P. T., \& McCrae, R. R. (2008). The Revised NEO Personality Inventory (NEO-PI-R).

Crawley, J. N. (2007). What's wrong with my mouse?: behavioral phenotyping of transgenic and knockout mice. John Wiley \& Sons.

Dawson, M. E., Rissling, A. J., Schell, A. M., \& Wilcox, R. (2007). Under what conditions can human affective conditioning occur without contingency awareness? Test of the evaluative conditioning paradigm. Emotion, 7(4), 755.

Day, R. E. (2001). The modern invention of information: Discourse, history, and power. SIU Press.

de la Fuente, J., Fernández-Cabezas, M., Cambil, M., Vera, M. M., González-Torres, M. C., \& ArtuchGarde, R. (2017). Linear relationship between resilience, learning approaches, and coping strategies to predict achievement in undergraduate students. Frontiers in Psychology, 8, 1039.

Decety, J., Jackson, P. L., Sommerville, J. A., Chaminade, T., \& Meltzoff, A. N. (2004). The neural bases of 
cooperation and competition: an fMRI investigation. Neuroimage, 23(2), 744-751.

Di Chiro, G., DeLaPaz, R. L., Brooks, R. A., Sokoloff, L., Kornblith, P. L., Smith, B. H., ... Johnston, G. S. (1982). Glucose utilization of cerebral gliomas measured by [18F] fluorodeoxyglucose and positron emission tomography. Neurology, 32(12), 1323.

Dimoka, A. (2012). How to Conduct a Functional Magnetic Resonance (fMRI) Study in Social Science Research. MIS Quarterly, 36(3), 811840. https://doi.org/10.2307/41703482

Dumas, G., Nadel, J., Soussignan, R., Martinerie, J., \& Garnero, L. (2010). Inter-brain synchronization during social interaction. PloS One, 5(8), e12166.

Edelman, G. M., Gally, J. A., \& Baars, B. J. (2011). Biology of consciousness. Frontiers in Psychology, 2, 4.

Edwards, P. K. (2013). Neuroscience and reductionism: Some realist reflections. Birmingham Business School Discussion Paper Series.

Ekman, P. E., \& Davidson, R. J. (1994). The nature of emotion: Fundamental questions. Oxford University Press.

Embick, D., Hackl, M., Schaeffer, J., Kelepir, M., \& Marantz, A. (2001). A magnetoencephalographic component whose latency reflects lexical frequency. Cognitive Brain Research, 10(3), 345-348.

Fässler, R., Martin, K., Forsberg, E., Litzenbarger, T., \& Iglesias, A. (1995). Knockout mice: How to make them and why. The immunological approach. International Archives of Allergy and Immunology, Vol. 106, pp. 323-334. https://doi.org/10.1159/000236862

Faturochman, F., Kurnianingsih, S., Kurniastuti, I., \& Fathoni, N. S. (2011). The Role of Inter Ethnic Marriage on Trustworthy and Caution. Jurnal Psikologi UGM, 38(1).

Ferguson, J. N., Young, L. J., \& Insel, T. R. (2002). The neuroendocrine basis of social recognition. Frontiers in Neuroendocrinology, 23(2), 200224.

Fiske, S. T., Cuddy, A. J. C., \& Glick, P. (2007). Universal dimensions of social cognition: warmth and competence. Trends in Cognitive Sciences, 11(2), 77-83. https://doi.org/10.1016/j.tics.2006.11.005

Forthmann, B., Holling, H., Çelik, P., Storme, M., \& Lubart, T. (2017). Typing speed as a confounding variable and the measurement of quality in divergent thinking. Creativity Research Journal, 29(3), 257-269.

Freeman, W. J., \& Rogers, L. J. (2002). Fine temporal resolution of analytic phase reveals episodic synchronization by state transitions in gamma EEGs. Journal of Neurophysiology, 87(2), 937945.

Fregni, F., Nitsche, M. A., Loo, C. K., Brunoni, A. R, Marangolo, P., Leite, J., ... Paik, N.-J. (2015).
Regulatory considerations for the clinical and research use of transcranial direct current stimulation (tDCS): review and recommendations from an expert panel. Clinical Research and Regulatory Affairs, 32(1), 22-35.

Fresan, A., Camarena, B., Apiquian, R., Aguilar, A., Urraca, N., \& Nicolini, H. (2007). Association study of MAO-A and DRD4 genes in schizophrenic patients with aggressive behavior. Neuropsychobiology, 55(3-4), 171175.

Frick, A., Åhs, F., Engman, J., Jonasson, M., Alaie, I., Björkstrand, J., ... Appel, L. (2015). Serotonin synthesis and reuptake in social anxiety disorder: a positron emission tomography study. JAMA Psychiatry, 72(8), 794-802.

Fukushi, T., Sakura, O., \& Koizumi, H. (2007). Ethical considerations of neuroscience research: The perspectives on neuroethics in Japan. Neuroscience Research, 57(1),10-16.

Gazzaniga, M., \& Heatherton, T. (2015). Psychological Science: Fifth International Student Edition. WW Norton \& Company.

Gazzaniga, M. S. (2014). Handbook of cognitive neuroscience. Springer.

Ghatak, S., Muthukumaran, R. B., \& Nachimuthu, S. K (2013). A simple method of genomic DNA extraction from human samples for PCR-RFLP analysis. Journal of Biomolecular Techniques : JBT, 24(4), 224-231. https://doi.org/10.7171/jbt.13-2404-001

Goense, J., Bohraus, Y., \& Logothetis, N. K. (2016). fMRI at high spatial resolution: implications for BOLD-models. Frontiers in Computational Neuroscience, 10, 66 .

Gold, J. I., \& Shadlen, M. N. (2007). The neural basis of decision making. Annual Review of Neuroscience, 30.

Goldberg, E., Harner, R., Lovell, M., Podell, K., \& Riggio, S. (1994). Cognitive bias, functional cortical geometry, and the frontal lobes: laterality, sex, and handedness. Journal of Cognitive Neuroscience, 6(3), 276-296.

Goldschmidt, A. B., Wonderlich, S. A., Crosby, R. D., Engel, S. G., Lavender, J. M., Peterson, C. B., ... Mitchell, J. E. (2014). Ecological momentary assessment of stressful events and negative affect in bulimia nervosa. Journal of Consulting and Clinical Psychology, 82(1), 30.

Greenberg, G. (2005). The limitations of behaviorgenetic analyses: Comment on McGue, Elkins, Walden, and Iacono (2005). Developmental Psychology, 41(6), 989-992. https://doi.org/10.1037/0012-1649.41.6.989

Greene, J. D., \& Paxton, J. M. (2009). Patterns of neural activity associated with honest and dishonest moral decisions. Proceedings of the National Academy of Sciences, 106(30), 12506-12511.

Guse, B., Falkai, P., \& Wobrock, T. (2010). Cognitive effects of high-frequency repetitive transcranial magnetic stimulation: a 
systematic review. Journal of Neural Transmission, 117(1), 105-122.

Hampshire, A., Highfield, R. R., Parkin, B. L., \& Owen, A. M. (2012). Fractionating human intelligence. Neuron, 76(6), 1225-1237.

Han, S., \& Northoff, G. (2008). Culture-sensitive neural substrates of human cognition: A transcultural neuroimaging approach. Nature Reviews Neuroscience, 9(8), 646.

Hansen, P., Kringelbach, M., \& Salmelin, R. (2010). MEG: an introduction to methods. Oxford university press.

Heatherton, T. F. (2004). Introduction to special issue on social cognitive neuroscience. Journal of Cognitive Neuroscience, 16(10), 1681-1682.

Hedden, T., Ketay, S., Aron, A., Markus, H. R., \& Gabrieli, J. D. E. (2008). Cultural influences on neural substrates of attentional control. Psychological Science, Vol. 19, pp. 12-17. https://doi.org/10.1111/j.14679280.2008.02038.x

Henry, J. C. (2006). Electroencephalography: basic principles, clinical applications, and related fields. Neurology, 67(11), 2092.

Herculano-Houzel, S. (2009). The human brain in numbers: a linearly scaled-up primate brain. Frontiers in Human Neuroscience, 3, 31.

Higgins, E. T. (2000). Social cognition: learning about what matters in the social world. European Journal of Social Psychology, 30(1), 3-39. https://doi.org/10.1002/(sici)10990992(200001/02)30:1<3::aidejsp987>3.0.co;2-i

Hofstede, G., Hofstede, G. J., \& Minkov, M. (2005). Cultures and organizations: Software of the mind (Vol. 2). Citeseer.

Horn, J. L., \& Cattell, R. B. (1966). Refinement and test of the theory of fluid and crystallized general intelligences. Journal of Educational Psychology, 57(5), 253.

Huang, B., Law, M. W.-M., \& Khong, P.-L. (2009). Whole-body PET/CT scanning: estimation of radiation dose and cancer risk. Radiology, 251(1), 166-174.

Huettel, S. A., Payne, J. W., Yoon, C., Gonzalez, R, Bettman, J., Hedgcock, W., \& Rao, A. (2009). Integrating neural and decision sciences: Convergence and constraints. Journal of Marketing Research, 46(1), 14-24.

Iacoboni, M. (2009). Imitation, empathy, and mirror neurons. Annual Review of Psychology, 60, 653-670.

Iacoboni, M., Lieberman, M. D., Knowlton, B. J., Molnar-Szakacs, I., Moritz, M., Throop, C. J., \& Fiske, A. P. (2004). Watching social interactions produces dorsomedial prefrontal and medial parietal BOLD fMRI signal increases compared to a resting baseline. Neuroimage, 21(3), 1167-1173.

Illes, J., \& Bird, S. J. (2006). Neuroethics: a modern context for ethics in neuroscience. Trends in Neurosciences, 29(9), 511-517.
Jacobson, L., Javitt, D. C., \& Lavidor, M. (2011). Activation of inhibition: diminishing impulsive behavior by direct current stimulation over the inferior frontal gyrus. Journal of Cognitive Neuroscience, 23(11), 3380-3387.

Jamaluddin, S. F., Adi, S. P., \& Lufityanto, G. (2020). Social influences on cheating in collectivistic culture: Collaboration but not competition. Group Dynamics: Theory, Research, and Practice. Advance online publication. https://doi.org/10.1037/gdn0000122

Ju Lan, T. (2011). Heterogeneity, politics of ethnicity, and multiculturalism: What is a viable framework for Indonesia? Wacana, 13(2), 279-292.

Kacen, J. J., \& Lee, J. A. (2002). The influence of culture on consumer impulsive buying behavior. Journal of Consumer Psychology, 12(2), 163176.

Kanai, R., Paulus, W., \& Walsh, V. (2010). Transcranial alternating current stimulation (tACS) modulates cortical excitability as assessed by TMS-induced phosphene thresholds. Clinical Neurophysiology, 121(9), 1551-1554.

Kantowitz, B. H., Roediger III, H. L., \& Elmes, D. G. (2014). Experimental psychology. Nelson Education.

Karton, I., Palu, A., Jõks, K., \& Bachmann, T. (2014). Deception rate in a "lying game": different effects of excitatory repetitive transcranial magnetic stimulation of right and left dorsolateral prefrontal cortex not found with inhibitory stimulation. Neuroscience Letters, 583, 21-25.

Kéri, S., \& Kiss, I. (2011). Oxytocin response in a trust game and habituation of arousal. Physiology \& Behavior, 102(2), 221-224.

Kidd, R. F. (1976). Manipulation checks: advantage or disadvantage? Representative Research in Social Psychology.

Klimesch, W., Schimke, H., \& Schwaiger, J. (1994). Episodic and semantic memory: an analysis in the EEG theta and alpha band. Electroencephalography and Clinical Neurophysiology, 91(6), 428-441.

Kosslyn, S. M., Cacioppo, J. T., Davidson, R. J., Hugdahl, K., Lovallo, W. R., Spiegel, D., \& Rose, R. (2002). Bridging psychology and biology: The analysis of individuals in groups. American Psychologist, 57(5), 341-351. https://doi.org/10.1037/0003-066X.57.5.341

Kowalczyk, W. J., Phillips, K. A., Jobes, M. L., Kennedy, A. P., Ghitza, U. E., Agage, D. A., ... Preston, K. L. (2015). Clonidine maintenance prolongs opioid abstinence and decouples stress from craving in daily life: a randomized controlled trial with ecological momentary assessment. American Journal of Psychiatry, 172(8), 760767.

Lajante, M. M. P., Droulers, O., \& Amarantini, D. (2017). How Reliable Are "State-of-the-Art" Facial EMG Processing Methods?: Guidelines 
for Improving the Assessment Of Emotional Valence in Advertising Research. Journal of Advertising Research, 57(1), 28-37.

Lamm, C., Batson, C. D., \& Decety, J. (2007). The neural substrate of human empathy: effects of perspective-taking and cognitive appraisal. Journal of Cognitive Neuroscience, 19(1), 4258.

Lanzenberger, R. R., Mitterhauser, M., Spindel egger, C., Wadsak, W., Klein, N., Mien, L.-K., ... Sacher, J. (2007). Reduced serotonin-1A receptor binding in social anxiety disorder. Biological Psychiatry, 61(9), 1081-1089.

Locke, E. A. (1965). The relationship of task success to task liking and satisfaction. Journal of Applied Psychology, 49(5), 379.

Logothetis, N. K., Pauls, J., Augath, M., Trinath, T., \& Oeltermann, A. (2001). Neurophysiological investigation of the basis of the fMRI signal. Nature, 412(6843), 150.

Lorberbaum, J. P., Kose, S., Johnson, M. R., Arana, G. W., Sullivan, L. K., Hamner, M. B., ... Bohning D. E (2004). Neural correlates of speech anticipatory anxiety in generalized social phobia. Neuroreport, 15(18), 2701-2705.

Lufityanto, G., Donkin, C., \& Pearson, J. (2016). Measuring intuition: nonconscious emotional information boosts decision accuracy and confidence. Psychological Science, 27(5), 622634.

Lufityanto, G., Purnamaningsih, E.H., Fitriani, S.D., Jehandut, B.A., Huda, T.N., Sarah, N., \& Abdillah, C.A.Z. (2019). Penggunaan peta visual terhadap kemampuan visual-spasial pengendara ojek online. Manuscript in Preparation

Lufityanto, G., Rahapsari, S., \& Kamal, I. (2020). Identifikasi stress terhadap perubahan melalui pengukuran kognitif dan respon hypothalamic-pituitary-adrenal. Jumal Psikologi Integratif, 7(2), 77-92.

Mantini, D., Corbetta, M., Romani, G. L., Orban, G. A, \& Vanduffel, W. (2012). Data-driven analysis of analogous brain networks in monkeys and humans during natural vision. Neuroimage, 63(3), 1107-1118.

Maxwell, S. E., Lau, M. Y., \& Howard, G. S. (2015). Is psychology suffering from a replication crisis? What does "failure to replicate" really mean? American Psychologist, 70(6), 487.

Milner, B., Squire, L. R., \& Kandel, E. R. (1998). Cognitive neuroscience and the study of memory. Neuron, 20(3), 445-468.

Minati, L., Visani, E., Dowell, N. G., Medford, N., \& Critchley, H. D. (2011). Variability comparison of simultaneous brain near-infrared spectroscopy and functional magnetic resonance imaging during visual stimulation. Journal of Medical Engineering \& Technology, 35(6-7), 370-376 https://doi.org/10.3109/03091902.2011.595 533
Montagu, J. D., \& Coles, E. M. (1966). Mechanism and measurement of the galvanic skin response. Psychological Bulletin, 65(5), 261.

Moorman, R. H., \& Podsakoff, P. M. (1992). A metaanalytic review and empirical test of the potential confounding effects of social desirability response sets in organizational behaviour research. Journal of Occupational and Organizational Psychology, 65(2), 131149.

Muellbacher, W., Ziemann, U., Boroojerdi, B., \& Hallett, M. (2000). Effects of low-frequency transcranial magnetic stimulation on motor excitability and basic motor behavior. Clinical Neurophysiology, 111(6), 1002-1007.

Naqvi, N. H., \& Bechara, A. (2006). Skin conductance: A psychophysiological approach to the study of decision making. Methods in Mind, 103-122.

Newport, C., Wallis, G., Reshitnyk, Y., \& Siebeck, U. E (2016). Discrimination of human faces by archerfish (Toxotes chatareus). Scientific Reports, 6, 27523.

Newsome, S., Day, A. L., \& Catano, V. M. (2000). Assessing the predictive validity of emotional intelligence. Personality and Individual Differences, 29(6), 1005-1016.

Nitsche, M. A., Cohen, L. G., Wassermann, E. M., Priori, A., Lang, N., Antal, A., ... Fregni, F. (2008). Transcranial direct current stimulation: state of the art 2008. Brain Stimulation, 1(3), 206223.

O'Craven, K. M., \& Kanwisher, N. (2000). Mental imagery of faces and places activates corresponding stimulus-specific brain regions. Journal of Cognitive Neuroscience, 12(6), 1013-1023.

Papadelis, C., Grant, P. E., Okada, Y., \& Preissl, H. (2015). Editorial on emerging neuroimaging tools for studying normal and abnormal human brain development. Frontiers in Human Neuroscience, 9, 127.

Pascual-Marqui, R. D., Michel, C. M., \& Lehmann, D. (1994). Low resolution electromagnetic tomography: a new method for localizing electrical activity in the brain. International Journal of Psychophysiology, 18(1), 49-65.

Pavlova, M., Guerreschi, M., Lutzenberger, W., Sokolov, A. N., \& Krägeloh-Mann, I. (2010). Cortical response to social interaction is affected by gender. Neuroimage, 50(3), 13271332.

Pfaus, J. G., Damsma, G., Nomikos, G. G., Wenkstem, D. G., Blaha, C. D., Phillips, A. G., \& Fibiger, H. C. (1990). Sexual behavior enhances central dopamine transmission in the male rat. Brain Research, 530(2), 345-348.

Purpura, D. P., \& McMurtry, J. G. (1965). Intracellular activities and evoked potential changes during polarization of motor cortex. Journal of Neurophysiology, 28(1), 166-185. 
Rizzolatti, G., \& Craighero, L. (2004). The mirrorneuron system. Annu. Rev. Neurosci., 27, 169192.

Rozin, P. (2001). Social psychology and science: Some lessons from solomon asch. Personality and Social Psychology Review, 5(1), 2-14. https://doi.org/10.1207/S15327957PSPR050 1_1

Sanfey, A. G., Loewenstein, G., McClure, S. M., \& Cohen, J. D. (2006). Neuroeconomics: cross-currents in research on decision-making. Trends in Cognitive Sciences, 10(3), 108-116.

Saxe, R. (2006). Uniquely human social cognition. Current Opinion in Neurobiology, 16(2), 235239. https://doi.org/10.1016/j.conb.2006.03.001

Schultz, W. (2007). Behavioral dopamine signals. Trends in Neurosciences, 30(5), 203-210.

Seloni, G. (2018). Mekanisme emotion-based learning yang dimoderatori risk-taking propensity dalam konteks pengambilan keputusan berisiko pada wirausaha dan non-wirausaha. Universitas Gadjah Mada.

Selye, H. (1950). Stress and the general adaptation syndrome. British Medical Journal, 1(4667), 1383.

Shadlen, M. N., \& Newsome, W.T. (2001). Neural basis of a perceptual decision in the parietal cortex (area LIP) of the rhesus monkey. Journal of Neurophysiology, 86(4), 1916-1936.

Shrout, P. E., \& Rodgers, J. L. (2018). Psychology, science, and knowledge construction: Broadening perspectives from the replication crisis. Annual Review of Psychology, 69, 487510.

Smedslund, J. (2016). Why Psychology Cannot be an Empirical Science. Integrative Psychological and Behavioral Science, 50(2), 185-195. https://doi.org/10.1007/s12124-015-9339-x

Song, A. W., Huettel, S. A., \& McCarthy, G. (2006). Functional neuroimaging: Basic principles of functional MRI. Handbook of Functional Neuroimaging of Cognition, 2, 22-52.

Spekman, R. E. (1979). Influence and information: An exploratory investigation of the boundary role person's basis of power. Academy of Management Journal, 22(1), 104-117.

Stagg, C. J., \& Nitsche, M. A. (2011). Physiological basis of transcranial direct current stimulation. The Neuroscientist, 17(1),37-53.

Stam, C. J. (2010). Use of magnetoencephalography (MEG) to study functional brain networks in neurodegenerative disorders. Journal of the Neurological Sciences, 289(1-2), 128-134.

Stefanski, V., \& Engler, H. (1999). Social stress, dominance and blood cellular immunity. Journal of Neuroimmunology, 94(1-2), 144152.

Stemmer, B., Segalowitz, S. J., Witzke, W., \& Schönle, P. W. (2004). Error detection in patients with lesions to the medial prefrontal cortex: an ERP study. Neuropsychologia,42(1), 118-130.
Sterzer, P., Stadler, C., Poustka, F., \& Kleinschmidt, A. (2007). A structural neural deficit in adolescents with conduct disorder and its association with lack of empathy. Neuroimage, 37(1), 335-342.

Sue Carter, C. (1998). Neuroendocrine perspectives on social attachment and love. Psychoneuroendocrinology, 23(8), 779-818. https://doi.org/10.1016/S03064530(98)00055-9

Sun, S., \& Yu, R. (2014). The feedback related negativity encodes both social rejection and explicit social expectancy violation. Frontiers in Human Neuroscience, 8, 556.

Taber-Thomas, B. C., Asp, E. W., Koenigs, M., Sutterer, M., Anderson, S. W., \& Tranel, D. (2014). Arrested development: early prefrontal lesions impair the maturation of moral judgement. Brain, 137(4), 1254-1261.

Tan, P. Z., Forbes, E. E., Dahl, R. E., Ryan, N. D., Siegle, G. J., Ladouceur, C. D., \& Silk, J. S. (2012). Emotional reactivity and regulation in anxious and nonanxious youth: A cell-phone ecological momentary ass essment study. Journal of Child Psychology and Psychiatry, 53(2), 197-206.

Teplan, M. (2002). Fundamentals of EEG measurement. Measurement Science Review, 2(2), 1-11.

Tong, F. (2003). Cognitive neuroscience: Primary visual cortex and visual awareness. Nature Reviews Neuroscience, 4(3), 219.

Triandis, H. C. (2001). Individual ism-collectivism and personality. Journal of Personality, 69(6), 907924.

Triantafyllou, C., Hoge, R. D., \& Wald, L. L. (2006). Effect of spatial smoothing on physiological noise in high-resolution fMRI. Neuroimage, 32(2), 551-557.

Trisia, M. A., Osozawa, K., \& Bai, H. (2016). How to Feed 311 Million of Indonesian People by 2050? Advancing Local Food Adaptation and Food Security Policy. KnE Life Sciences, 49-54.

Valkenburg, P. M., Peter, J., \& Schouten, A. P. (2006). Friend networking sites and their relationship to adolescents' well-being and social selfesteem. CyberPsychology \& Behavior, 9(5), 584-590.

Weisel, 0.,\& Shalvi, S. (2015). The collaborative roots of corruption. Proceedings of the National Academy of Sciences of the United States of America, 112(34), 10651-10656. https://doi.org/10.1073/pnas.1423035112

Wexler, B. E., Warrenburg, S., Schwartz, G. E., \& Janer, L. D. (1992). EEG and EMG responses to emotion-evoking stimuli processed without conscious awareness. Neuropsychologia, 30(12), 1065-1079.

Wheless, J. W., Castillo, E., Maggio, V., Kim, H. L., Breier, J. I., Simos, P. G., \& Papanicolaou, A. C. (2004). Magnetoencephalography (MEG) and magnetic source imaging (MSI). The Neurologist, 10(3), 138-153. 
Wilson, S. J., Smyth, J. M., \& MacLean, R. R. (2013). Integrating ecological momentary assessment and functional brain imaging methods: new avenues for studying and treating tobacco dependence. Nicotine \& Tobacco Research, 16(Suppl_2), S102-S110.

Winston, J. S., Strange, B. A., O'Doherty, J., \& Dolan, R. J. (2002). Automatic and intentional brain responses during evaluation of trustworthiness of faces. Nature Neuroscience, $5(3), 277$

Wu, Y., Leliveld, M. C., \& Zhou, X. (2011). Social distance modulates recipient's fairness consideration in the dictator game: An ERP study. Biological Psychology, 88(2-3), 253262.

Xiang, Y., Kong, F., Wen, X., Wu, Q., \& Mo, L. (2016). Neural correlates of envy: regional homogeneity of resting-state brain activity predicts dispositional envy. Neuroimage, 142, 225-230.

Zahrani, D. D., \& Lufityanto, G. (2019). Redefining Career Success in Agile Companies: A Psychophysical Approach. Universitas Gadjah Mada. 
Lampiran 1. Contoh penelitian Social Neuroscience yang telah dilakukan

\begin{tabular}{|c|c|c|c|}
\hline Penulis (Tahun) & Perilaku Sosial & $\begin{array}{l}\text { Elemen Biologis yang } \\
\text { Diteliti }\end{array}$ & Temuan Spesifik \\
\hline $\begin{array}{l}\text { (Sterzer, Stadler, } \\
\text { Poustka, \& } \\
\text { Kleinschmidt, } \\
\text { 2007) }\end{array}$ & $\begin{array}{l}\text { Empati terhadap } \\
\text { orang lain }\end{array}$ & $\begin{array}{l}\text { Area amygdala dan } \\
\text { anterior insular cortex } \\
\text { pada otak }\end{array}$ & $\begin{array}{l}\text { Sejumlah pasien yang mengalami } \\
\text { conduct disorder (CD) dan } \\
\text { menunjukkan perilaku non-empatik } \\
\text { pada orang lain ditemukan secara } \\
\text { konsisten mengalami disfungsi pada } \\
\text { bagian otak amygdala kiri dan anterior } \\
\text { insular cortex. }\end{array}$ \\
\hline $\begin{array}{l}\text { (Taber-Thomas } \\
\text { dkk., 2014) }\end{array}$ & $\begin{array}{l}\text { Pengambilan } \\
\text { keputusan moral }\end{array}$ & $\begin{array}{l}\text { Area prefrontal cortex } \\
\text { pada otak }\end{array}$ & $\begin{array}{l}\text { Pasien yang mengalami kerusakan } \\
\text { poada bagian ventromedial prefrontal } \\
\text { cortex cenderung bersikap egoistik } \\
\text { dengan melanggar prinsip moralitas } \\
\text { dan karenanya merugikan oranglain. }\end{array}$ \\
\hline $\begin{array}{l}\text { (Fresan dkk., } \\
\text { 2007) }\end{array}$ & Perilaku agresif & $\begin{array}{l}\text { Gen DRD } 4 \text { dan gen } \\
\text { MAO-A }\end{array}$ & $\begin{array}{l}\text { Penderita schizophrenia yang } \\
\text { mengalami mutasi pada gen DRD4 dan } \\
\text { MAO-A menunjukkan perilaku agresif } \\
\text { daripada pasien lain yang gen DRD4 } \\
\text { dan MAO-A-nya normal. }\end{array}$ \\
\hline $\begin{array}{l}\text { (Ferguson, Young, } \\
\text { \& Insel, 2002) }\end{array}$ & Rekognisi sosial & $\begin{array}{l}\text { Hormon vasopressin } \\
\text { dan oxytocin }\end{array}$ & $\begin{array}{l}\text { Hormon vasopressin dan oxytocin pada } \\
\text { bagian lateral septum memperkuat } \\
\text { memori terhadap orang lain (memori } \\
\text { sosial). }\end{array}$ \\
\hline $\begin{array}{l}\text { (Pfaus dkk., } \\
\text { 1990) }\end{array}$ & Perilaku seksual & Hormon dopamine & $\begin{array}{l}\text { Penelitian pada subjek tikus } \\
\text { menunjukkan bahwa tikus jantan } \\
\text { mengalami pelasan } \\
\text { neurotransmitter dopamine pada } \\
\text { nucleus accumben ketika } \\
\text { menunjukkan perilaku seksual dengan } \\
\text { tikus betinayang baru. }\end{array}$ \\
\hline $\begin{array}{l}\text { (Sue Carter, } \\
\text { 1998) }\end{array}$ & $\begin{array}{l}\text { Menyayangi orang } \\
\text { lain }\end{array}$ & $\begin{array}{l}\text { Hormon hypothalamic- } \\
\text { pituitary-adrenal } \\
\text { (HPA) }\end{array}$ & $\begin{array}{l}\text { Hormon yang dihasilkan oleh axis HPA } \\
\text { ditemukan mempengaruhi ikatan } \\
\text { sosial (social bonding). }\end{array}$ \\
\hline $\begin{array}{l}\text { (Lanzenberger } \\
\text { dkk., 2007) }\end{array}$ & Kecemasan sosial & Hormon serotonin & $\begin{array}{l}\text { Kurangnya hormon serotonin (5- } \\
\text { HT }_{1 \mathrm{~A}} \text { ) pada subjek manusia } \\
\text { menyebabkan kecenderungan } \\
\text { kecemasan sosial. Studi dilakukan } \\
\text { dengan metode positron emission } \\
\text { tomography (PET). }\end{array}$ \\
\hline $\begin{array}{l}\text { (Stefanski \& } \\
\text { Engler, 1999) }\end{array}$ & Stres sosial & Sel darah putih & $\begin{array}{l}\text { Penelitian pada subjek tikus jantan } \\
\text { yang bertarung merebutkan tikus } \\
\text { betina menunjukkan bahwa tikus } \\
\text { jantan yang kalah bersaing dan } \\
\text { memperlihatkan stres, menderita } \\
\text { kekurangan sel darah putih CD4 and } \\
\text { CD8 yang berfungsi pada sistem } \\
\text { kekebalan tubuh. }\end{array}$ \\
\hline
\end{tabular}

